\title{
The Early History of the Cell Theory
}

T is now genorally recognised that Schwann was not the first to discover cells in the body of an animal but he is often regarded as the founder of the theory of the conformity in the elementary structure of plants and animals. In a recent number of the Anatomischer Anzeiger Prof. F. K. Studnicka shows that Schwann was neither the first to make this sug. gestion, nor did he really prove it. He has studied the work of all the forerunners of Schwann and has attempted systematically to interpret the significance of their work.

In $1823 \mathrm{H}$. Milne Edwards came to the conclusion that the small granules ('globules') of $1 / 300 \mathrm{~mm}$. in diameter, which he found in all the tissues he examined, aro of varied origin and in great part mere artefacts. Henry Dutrochet (1824) accepted some of H. Milne Edwards's ideas (he had seen the same globules), but he mado a great advanco by directing attention to cells in the modern sense, as typified for example in the ganglion cells of Helix and Arion and the cells in the glands of Helix. In his opinion, the globules of Milne Edwards develop into small vesicles, that is, cells. He compared these animal colls not with the 'great' plant cells, but with the small 'cells', found in the walls of the latter, which probably are plastids and starch granules. According to Dutrochet, the difference between the cells of animals and those of plants lies in the fact that in plants they develop much farther than in animals and give origin to large vesicular formations, whereas in animals they retain the globular form. Dutrochet was completely mistaken in describing such 'cells' in animals, because the 'cell' (that is, the cell in plants) of those times conformed to the usual meaning of this word in English. It corresponded to what we call the cell membrane. As is well known, such cells are only exceptionally present in the tissues of animals. Rich, who has dealt with Dutrochet's work moro recently (1926), takes into consideration only Dutrochet's conclusions, some of which happen to agree with our modern ideas, but he overlooks the fact that these conclusions were not sufficiently proved and were, therefore, mere speculations. Dutrochet foreshadowed the cell theory but he was not the founder of the latter.

Raspail (1827) distinguished small and large 'globules' (erythrocytes, for example) and 'cells' and pointed out that the latter may assume a very elongated form, for example, muscle, nerve.

H. Milne Edwards's observations of globules in the body of animals had some influence upon contem. porary literuture, but to Dutrochet's and Raspail's theories of the essential identity of the 'cells' of both plants and animals, no special attention was paid. They were regarded, not quite without justification, as unproved.

In 1835, Purkinje's pupil G. Valentin described 'granules' in the body of an embryo, 'globules' in the chorda dorsalis and 'cells' in the cartilage of the larvæ of the frog. Another pupil of Purkinje, Raschkow, described (1835) cells in the epithelium of the gums and directed attention to the similarity of the latter to the cells of plants. Following on Purkinje's description in 1825 of the vesicula gorminativa in the ovum of birds and the discovery by $R$. Brown, in 1831, of the nucleus in plant cells, these authors also describod the existence of the cell nuclous in animal cells, which had not been observed by
Dutrochot and Raspail. In 1836, Johannes Müller rediscovered the cells of the chorda and cartilage.

In 1837, Purkinje communicated to a mesting of the German Men of Science and Physicians in Prague a short note on a theory of the conformity in the microscopic structures of plants and animals and directod attention to the differences between them. This was not a cell theory, and even later Purkinje firmly rejocted Schwann's cell theory (1839, 1840). The great advance he made, however, was that he no longer attempted like other workers to discover the plant 'cell' in the body of animals. (We must here bear in mind that the 'coll' of Purkinje's con. temporaries corresponded to the cell wall or the cell membrane in the modern sense.) Purkinje did not describe 'cells' in animals, but, more correctly, 'granules' (Körnchen), quite different from the 'globules' of $\mathrm{H}$. Milne Fdwards, and formed by a special vital substance containing a nucleus. For this vital substance, he was the first to use the term 'protoplusma' and he concluded that this substance and not the outer part, or cell membrane as we would call it to-day, formed the essential constituent of the 'granules'.

Studnieka has dealt with Purkinje's work in a special paper: "Purkinjes und seiner Schüler Verdienste um die Zelltheorie"1. He points out that J. F. Purkinje (professor of physiology in Breslau and from 1851 in Prague) is to be looked upon as one of the founders of oxperimental physiology and modern histology and microscopical anatomy. Ho was one of the first to give an account of the methods for the study of the animal tissues and in a series of papers in conjunction with his pupils described in detail the structure of the chief tissues of the animal body. In particular Purkinje and his pupils described the 'granules' in these tissues, which represent the cells of modern histology, and so to this school (of which Valentin was a vory prominent member) belongs the distinction of having been the first to recognise the manifold variety of cells in the animal body. The school of Johannes Müller also discovered the cells of the animal tissues independently, but their observations were published later than those of the Purkinje school.

Notwithstanding the advances made by the Purkinje school, Schwann $(1838,1839)$ in his wellknown book (in which he developed his own cellular theory) returned to the views of Wolff, Oken and Dutrochet. For him, the outer part (cell membrane in the modern sense) was the essential constituent of the 'cell' and ho attached no special importance to the cell contents. Nevertheless his views came? to be widely accepted and quite overshadowed those of Purkinje, the consequence being that his name became associated with that of Schleiden as the joint founder of the cell theory. So far as the completely mistaken theory of cytogenesis which these two writers advocated is concerned, this was no doubt justified; but Schleiden and Schwann aro usually regarded as the founders of the cell theory in the modern sense without any qualification. Even Haeckel regarded Schleiden as the first to extend tho cell theory to plants but the botanists never paid great attention to Schleiden's erroneous discoveries, and it is, therefore, the moro remarkable that to Schleiden alone was attributed such an important part in the history of the histology of animals.

No. 3286, VoL. 130] 
Schwann introduced Schleiden's errors into animal histology, reinforced by one of his own, namely, the idea that new cells originate chiefly between the old cells, not within them. On these mistaken ideas (the wrong definition of the cell and erroneous ideas of cell formation) Schwann built up his theory of the "conformity in the structure and the development of the cells in animals and plants". It remained for Max Schultze to correct, twenty-two years later (1861), the errors of Schwann's theory in the sense of Purkinje's ideas.

\section{J. FLORIAN.}

Anat. Anzeiger, 1927, and Acta Soc. natur., Brno, 1927.

\section{The 'Butterfly' Map Projection}

$\mathrm{T}$ HE problem of reducing the sphere to a plane surface has ever been a difficulty. This realisation has led cartographers to adopt the policy of constructing a map for a specific purpose. The most important features which have to be embodied in maps may be classified in three categories: (1) exactness of shape; (2) exactness of area; (3) exactness of relative position. Whichever of these features will be required is decided by the purpose a substitute for the globe and on development is a spherical representation and not a reproduction. The cube of the gnomonic projection is replaced by this modified octahedron.

The other unusual figure is the combination of various projections, namely, 1, 2 and 3 . This gives rise to a grave defect when one remembers that an essential feature of any map is ease of interpretation. A form of projection frequently employed for statis-

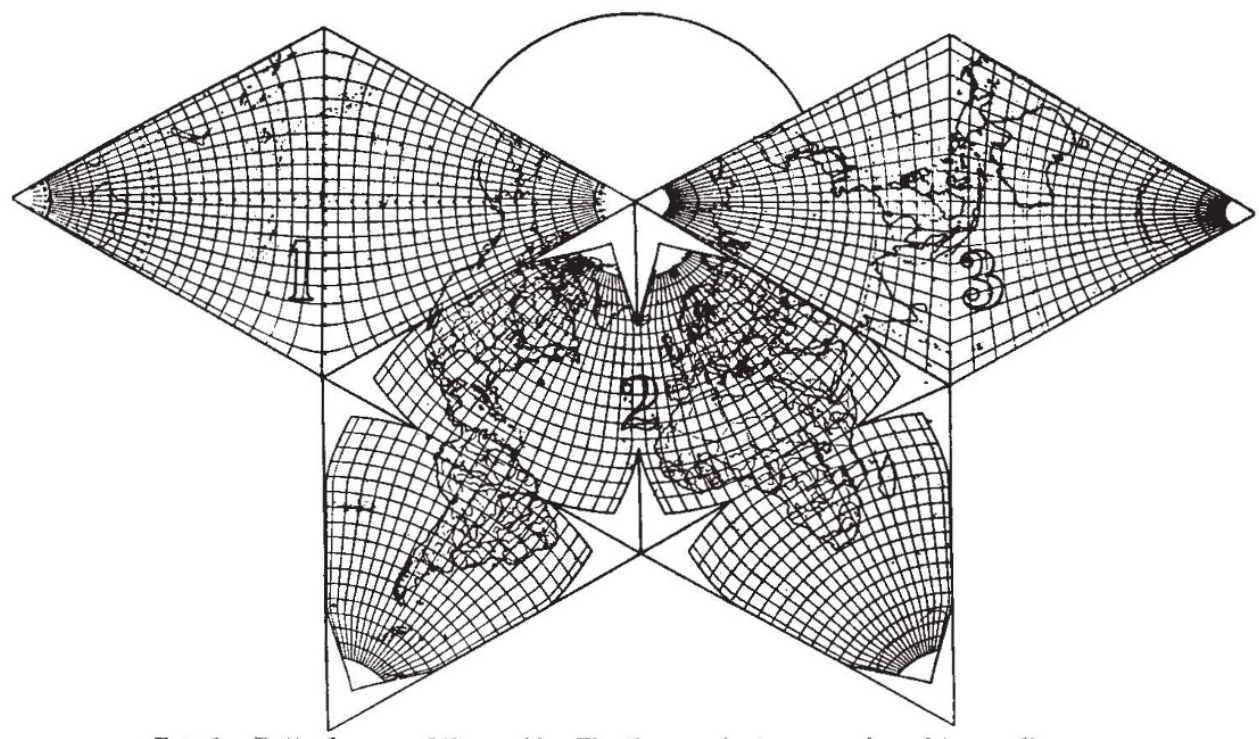

Fir. 1. Butterfly map of the world. The three variants are condensed to one diagram.

of the map, and when this has been decided a map is constructed on an appropriate projection. The required feature is embodied in the map, the others are ignored, with the result that distortion in some respect is usually apparent.

Mr. B. J. S. Cahill, of Oakland, California, has regarded this problem from a fresh angle. Instead of making one purpose dictate the form of the whole map, he has realised that in a world map the land areas may be required for one purpose and the water for another. There is also the uneven distribution of land and water over the globe.

The resultant map, constructed to serve many purposes, has been achieved by incorporating various projections into one final form, and by representing the globe by an octahedron (Fig. 1). Such a figure is capable of being more closely approximated to the sphere by the addition, on either face of the octahedron, of smaller tetrahedrons. Thus the principles of triangulation as applied in plane work are translated to the solid. Such an octahedron with tetrahedral modifications can easily be developed into a plane surface.

It must, however, be noticed that such a figure is tical purposes is that of Mollweide. This is an equal area of projection and when constructed with the Greenwich meridian in the middle of the map, areas in remoter longitudes assume very distorted shapes. To obviate this difficulty the usual form of the pro. jection is replaced by an interrupted form. Against such forms there has always been the accusation that they are not easy to read.

In the case of the 'butterfly' map this criticism will be made, and strongly asserted, because the continuative feature is missing. The faces numbered 2 do not conform to the original octahedral boundaries, whilst the junctions of the portions 1 with 2,2 with 3 are not too happily made. Such breaches of continuity as are evidenced in tracing the $5^{\circ} \mathrm{N}$. latitude and in north-west India (sheets 2 and 3 ) will require more than supplementing by simple graphic diagrams.

The use of this modified octahedron instead of a single plane is an advantage, but it cannot give a sphere, whilst the discontinuity due to the unhappy alliance of divers projections will scarcely "help mankind to learn to think planetarily".

J. E. Coleclough.

No. 3286, Vol. 130] 